\title{
Occupational accidents among the nurses
}

\author{
A Özarslan \\ From International Conference on Prevention \& Infection Control (ICPIC 2011) \\ Geneva, Switzerland. 29 June - 2 July 2011
}

\section{Introduction / objectives}

This is a cross sectional study designed to define factors which affect the frequency, distribution, types and notification of occupational accidents in the nurses working in Gulhane Military Medical Academy.

\section{Methods}

In this study, 504 of 570 nurses were reached. All of these nurses were applied a questionnaire related with occupational accidents. An observational study was made for occupational accidents, which they experienced 2009, were performed. The accidents were detected either by using a notification form or by periodical observations during the period. Arithmetic mean and frequency analyses were used for analyzing the data and chi-square test was applied for comparison of the groups. In the analysis $\mathrm{a}=0,005$ value was chosen as error margins.

\section{Results}

According to results of study; $43.1 \%$ of the nurses declared they experienced an occupational accident in the last year, $53 \%$ declared individual protective equipment was partially supplied. The $50 \%$ of the participants stated only a moderate level of safety precautions was provided due to their occupational risks. In a threemonth period, frequency rate of occupational accidents was $8.1 \%$, and density rate was $24 / 1000$ per 100 hours. Sharp injury accident was the first with $70.7 \%$. The most frequent exposure type was the needle-stick injury of hand fingers.Regarding the accident as unimportant was the main reason for ignoring declaration. No attempt for medical advice was made for thirty (73.1\%) accidents. The risk for occupational accidents was increased with the overtime working $(p=0.039)$. The nurses experiencing occupational accidents realize the

Infection Control Commitee, Gülhane Military Medical Academy, Ankara, Turkey

(c) 2011 Özarslan; licensee BioMed Central Ltd. This is an open access article distributed under the terms of the Creative Commons Attribution License (http://creativecommons.org/licenses/by/2.0), which permits unrestricted use, distribution, and reproduction in any medium, provided the original work is properly cited. preventive measures for occupational risks to be at moderate level $(\mathrm{p}=0.011)$.

\section{Conclusion}

In conclusion, the educational level of the nurses for occupational health and safety are not adequate. Occupational health and safety should be under the supervision of a board, which must include must include experts.

\section{Disclosure of interest \\ A. Özarslan Other MSN}

Published: 29 June 2011

doi:10.1186/1753-6561-5-S6-P288

Cite this article as: Özarslan: Occupational accidents among the nurses. BMC Proceedings 2011 5(Suppl 6):P288.

Submit your next manuscript to BioMed Central and take full advantage of:

- Convenient online submission

- Thorough peer review

- No space constraints or color figure charges

- Immediate publication on acceptance

- Inclusion in PubMed, CAS, Scopus and Google Scholar

- Research which is freely available for redistribution Submit your manuscript at
www.biomedcentral.com/submit C BioMed Central 